Gut, 1967, 8, 614

\title{
Risk of anicteric hepatitis following blood transfusion
}

\author{
B. N. SOMAYAJI, W. D. STONE ${ }^{1}$, AND P. B. GLOVER \\ From the Departments of Medicine and Biochemistry, Dudley Road Hospital, Birmingham
}

EDITORIAL COMMENT The considerable risk of overt or anicteric hepatitis following blood transfusion reported from various countries has not been confirmed in England. This may be due to the careful selection of blood donors and to the fact that they are volunteers. Volunteers are known to have a lower incidence of silent virus carriers than professional donors.

Serum hepatitis can bea serious complication of blood transfusion, and it is possible that even mild attacks may lead to cirrhosis, although evidence for this is scanty. The incidence of icteric hepatitis following blood transfusion was found to be $0.8 \%$ in Liverpool by Lehane, Kwantes, Upward, and Thomson (1949), but in other countries higher figures have been obtained. For example, Katz, Ducci, Bennett, and Rodríguez (1957) reported an incidence of over $4 \%$ in Chile, while in the U.S.A. it was 3\% (Allen and Sayman, 1962) and 4\% (Mirick, Ward, and McCollum, 1965) in two large series.

The anicteric form of hepatitis, diagnosed on the basis of raised serum transaminases and sometimes confirmed by biopsy, appears to be much more common. It has been suggested that it occurs between 10 (Shimizu and Kitamoto, 1963) and 100 times (Hampers, Prager, and Senior, 1964) as often as hepatitis with jaundice, the diagnosis being made in $13.5 \%$ of transfused patients in a German report (Creutzfeldt, 1966) and in 64.5\% in one from Japan (Shimizu and Kitamoto, 1963) (see table). In the Philadelphia series (Hampers et al., 1964) all patients who received 6 or more units of blood contracted hepatitis.

We report below the findings of a study, carried out in an attempt to assess the importance of this complication, in the Birmingham region.

\section{PATIENTS AND METHODS}

Forty-five patients were studied. Two received blood transfusion for bleeding peptic ulcer, and the remainder were inpatients in the gynaecological wards. Their disorders included abortions, fibroids, dysfunctional uterine bleeding, and ruptured ectopic pregnancy. Those with carcinoma were excluded. Patients who had no clinical

'Present address: Department of Medicine, Queen Elizabeth Hospital, Birmingham, 15. evidence of liver disease and did not propose to take oral contraceptives during the next six months were included in the study. Serum aspartate aminotransferase (AsT.; S.G.O.T.) and alanine aminotransferase (AIT.; S.G.P.T.) were estimated at the time of admission to the series, in addition to standard liver function tests which included estimations of plasma proteins, serum bilirubin, thymol turbidity, and alkaline phosphatase. The blood samples for these tests were taken either immediately before or soon after transfusion.

Patients were re-examined in the outpatient clinic during the third or fourth week after transfusion and thereafter every two weeks until the fourteenth week and finally during the eighteenth and twenty-second weeks. Blood was taken at each visit for the estimation of AsT. and AIT. Whenever the serum enzyme level was found to be elevated, patients were recalled, examined, and the full series of liver function tests repeated. Forty-two of the 45 patients continued to attend until the twenty-second week. Three attended until the tenth week, after which one left the country and the other two could not attend for personal reasons; they have therefore been excluded.

The procedure used for the estimation of the aminotransferases was the colorimetric method of Reitman and Frankel (1957) using a pyruvate standard curve. The incubation of the enzyme and substrate was carried out at $37^{\circ} \mathrm{C}$. At the beginning of this study, the results were expressed in Sigma-Frankel (S.F.) units for which the normal ranges are: AsT. 8-40 units per ml., AlT. 5-35 units per ml. Later in the study, the results were reported in I.U. per litre as recommended in the Report of the Commission on Enzymes (International Union of Biochemistry, 1961), giving new normal ranges of 4 to 20 I.U. per litre and 2 to 15 I.U. per litre for AsT. and AIT. respectively.

\section{RESULTS}

The ages of the 42 patients ranged from 18 to 70 years with a mean of 37.8 years (Fig. 1). A total of 128 units of blood, each $540 \mathrm{ml}$., was given (Fig. 2), 21 patients receiving three or more units. One patient had had infectious hepatitis 13 years before. 


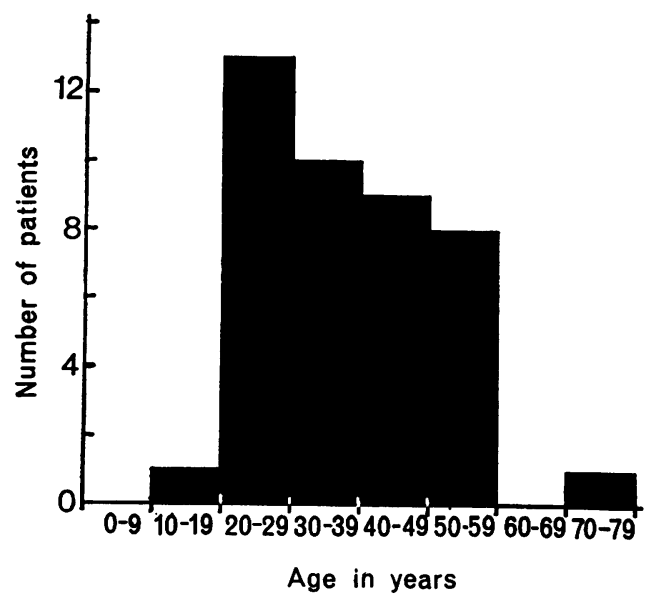

FIG. 1. The age distribution of the 42 patients studied.

Six had had previous transfusions, but the time interval between the two transfusions was over 12 months in all of them.

In four patients the serum enzyme levels were elevated at the first estimation, the highest level being 65 I.U. per litre. However, these blood samples had been taken 24-48 hours after operations under general anaesthetic, and in each case the levels had fallen to normal by the first follow-up visit, remaining within the normal range throughout the next 18 weeks.

Only two of the 42 patients showed transient elevation of serum aminotransferases during the period of observation. In both, only the AsT. level

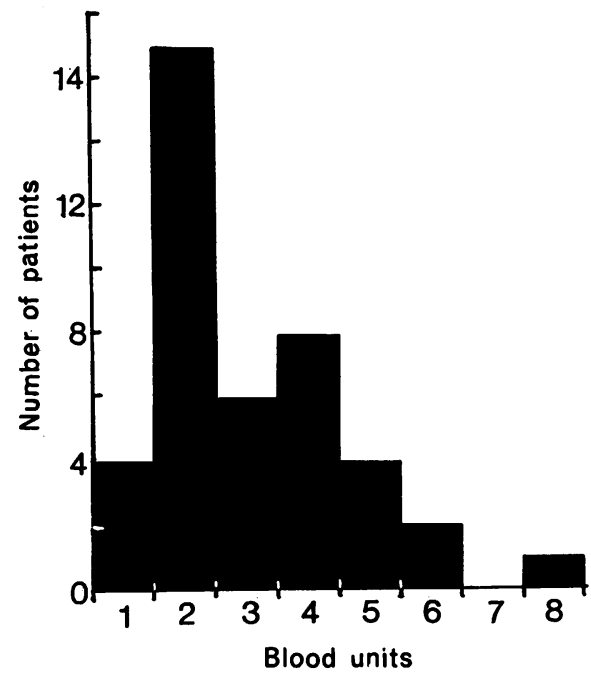

FIG. 2. The distribution of 128 units of blood among the 42 patients.

was elevated, and when the enzyme estimation was repeated a week later, it was found to be well within the normal range. Their general health remained good and they did not complain of lethargy, anorexia, or nausea. The course of serum enzyme levels in these two patients is shown in Figure 3. One of them (B.S.) was admitted for liver biopsy which showed normal liver tissue. At the same time, other liver function tests were also normal and bromsulphthalein (B.S.P.) retention at 30 minutes after an intravenous dose of $5 \mathrm{mg}$. per kilogram bodyweight was only $1 \%$.

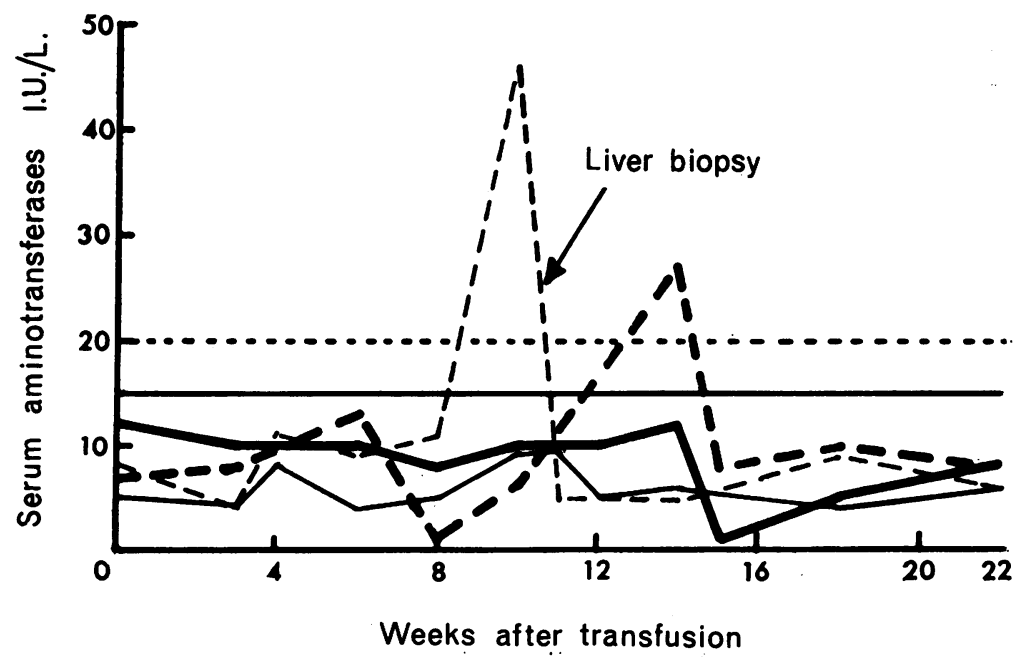

FIG. 3. The levels of serum AsT. $(===)$ and $A l T .(-)$ in two patients, B.S. (thin lines) and P.B. (thick lines). The horizontal lines at 15 and 20 represent upper limits of normal for $A l T$. and $A s T$. respectively. 


\section{DISCUSSION}

Previous studies have set criteria for making the diagnosis of anicteric hepatitis. Shimizu and Kitamoto (1963) considered that the S.G.P.T. should reach a maximum level of more than 90 units (normal $<35$ ) and should remain above 50 units for over two weeks. Of their 175 patients, 113 developed changes of this magnitude and liver biopsy performed in 10 confirmed the diagnosis. Hampers et al. (1964) found raised transaminase levels in 10 patients, the elevations persisting for over three weeks. Some of their patients had symptoms of lethargy, anorexia, and nausea, and six had increased retention of B.S.P. and abnormal liver biopsies. A similar pattern of elevation of serum transaminases was reported by Creutzfeldt (1966).

By these criteria we discovered no instance of anicteric hepatitis in this series. We do not consider the slight and transient elevations of AsT. seen in two patients to be significant. This belief is supported by the finding of a normal liver biopsy and B.S.P. retention in one patient and by the absence of clinical symptoms in both. No other patient showed any rise of enzyme levels.

These results are very different from experience in other countries (see table). Although the number of patients whom we have studied is small, it is comparable to that of Hampers et al. (1964), who found 10 cases of hepatitis, seven of which were among the 11 patients who received 3 or more units of blood. It is generally believed that the incidence of hepatitis is directly related to the amount of blood received (Allen and Sayman, 1962; Shimizu and Kitamoto, 1963). In the present study, there were 21 patients who received 3 or more units of blood and none developed hepatitis.

It is likely that some cases of anicteric hepatitis would be discovered if very large numbers of transfused patients were carefully followed up, but the incidence appears to be much lower in Britain than elsewhere. Two possible explanations for this may be the existence of the National Blood Transfusion Service, based entirely on voluntary donations, and a low incidence of 'silent carriers' of viral hepatitis in the community.

There is ample evidence that recipients of blood from professional donors develop hepatitis much more frequently than those receiving voluntary donations (Allen, Dawson, Sayman, Humphreys, Benham, and Havens, 1959; Shimada Fukuda, Ishii, Sekikawa, Ohtsuki, Matsuda, Kodeki, Ohya, Nagao, Kimura, Nakano, Murakami, Miyamoto, and Tsuchiya, 1965; Grady, Chalmers, and the Boston Inter-hospital liver group, 1964). Norris, Potter, and Reinhold (1963) found a three-fold greater incidence of abnormal hepatic function tests in a group of mainly 'professional walk-in donors' as compared with another group who gave blood for friends and relatives. Anderson, Lou, and Allen (1965) did not find a single voluntary donor whose S.G.O.T. or S.G.P.T. level was more than 100 units (normal $<40$ ), whereas $1.7 \%$ of a professional group had S.G.O.T. levels higher than this. When the donors' S.G.O.T. levels were over 100 units, $5.5 \%$ of the recipients developed hepatitis compared with $1.5 \%$ when they were below 40 units (Bang, Ruegsegger, Ley, and Ladue, 1959). The most important factor in lowering the risk of post-transfusion hepatitis is probably, therefore, the maintenance of high standards for selecting donors.

In Birmingham, blood is supplied from the regional Blood Transfusion Centre, and donors are entirely voluntary and unpaid. At present no transaminase estimations are carried out, but donors are specifically questioned about a past history of infectious hepatitis, glandular fever, malaria, recent contact with an infectious disease, and recent inoculations or vaccinations. Those answering in the affirmative are excluded. These efforts to screen donors may be partly responsible for the satisfactory results of this study.

The incidence of infectious hepatitis varies in different parts of the world, and cyclic fluctuations have been observed in the U.S.A. (McCollum, 1962) and in Denmark (Havens, 1961-62). When the hospital admission rate for infectious hepatitis increased among adult residents in Boston between

TABLE

\begin{tabular}{|c|c|c|c|c|c|c|c|c|c|}
\hline \multirow{3}{*}{ Author } & \multicolumn{9}{|c|}{ REPORTED INCIDENCE OF HEPATITIS AFTER BLOOD TRANSFUSION } \\
\hline & Country & No. of & Total No. & Average & Follow-up 1 & No. of & es of Hepa & itis & Incidence \\
\hline & & & & Patient & & Icteric & Anicteric & Total & itis (\%) \\
\hline $\begin{array}{l}\text { Shimizu and Kitamoto (1963) } \\
\text { Creutzfeldt (1966) }\end{array}$ & $\begin{array}{l}\text { Japan } \\
\text { Germany }\end{array}$ & $\begin{array}{l}175 \\
208\end{array}$ & $\begin{array}{l}1,907^{1} \\
150(1-3) \\
58(>3)\end{array}$ & $\begin{array}{l}10 \cdot 7^{1} \\
\text { Not stated }\end{array}$ & $\begin{array}{l}3 \text { months } \\
41 \text { months }\end{array}$ & $\begin{array}{r}10 \\
6\end{array}$ & $\begin{array}{r}103 \\
22\end{array}$ & $\begin{array}{r}113 \\
28\end{array}$ & $\begin{array}{l}64 \cdot 5 \\
13 \cdot 5\end{array}$ \\
\hline Hampers et al.(1964) & U.S.A. & 56 & 115 & $2 \cdot 1$ & $\begin{array}{l}6 \text { months } \\
\text { or more }\end{array}$ & $\mathbf{0}$ & 10 & 10 & 18 \\
\hline $\begin{array}{l}\text { Present study } \\
{ }^{1} \text { Each } \text { unit }=200 \mathrm{ml} \text {. }\end{array}$ & U.K. & 42 & 128 & 3.05 & $5 \frac{1}{2}$ months & 0 & $\mathbf{0}$ & $\mathbf{0}$ & - \\
\hline
\end{tabular}


1953 and 1955, a similar increase in post-transfusion hepatitis was seen, especially among recipients of commercially supplied blood (Grady et al., 1964). The epidemiological pattern of viral hepatitis in this country is not known since the condition is not generally notifiable, but there is evidence that the incidence has been lower during the last two years in some of the areas where notification is in force (Rowland, Skone, Wofinden, and Wood, 1967). It is uncertain whether this applies to Birmingham where the disease is not notifiable, but a low incidence of carriers of the virus in the community is probably another factor contributing to the apparent safety of blood transfusion.

Mirick et al. (1965) have demonstrated a three- to fourfold reduction in the incidence of post-transfusion hepatitis with jaundice by the administration of gamma globulin, but they were unable to show any beneficial effect on the frequency of anicteric hepatitis. Torii, Nakano, and Miyazato (1965), on the other hand, found gamma globulin to exert some protection against both the icteric and anicteric forms. Routine prophylaxis with gamma globulin does not appear to be indicated in this country except, perhaps, in patients undergoing open-heart surgery and in elderly, debilitated individuals.

\section{SUMMARY}

None of 42 patients whose serum aminotransferase levels were estimated regularly after blood transfusion developed hepatitis. The possible causes for this, which is unlike the experience of workers in other countries, are discussed.

We should like to thank Mr. E. Cope, Mr. G. Mitchell and Miss A. L. Reynolds for permission to study their patients, Dr. A. Paton for helpful suggestions and encouragement throughout this study, and Mr. W. B. Yeoman for providing facilities for the aminotransferase estimations. Dr. G. W. G. Bird, regional director of the
National Blood Transfusion Service, kindly discussed with us the procedure used for screening blood donors.

\section{REFERENCES}

Allen, J. G., Dawson, D., Sayman, W. A., Humphreys, E. M., Benham, R. S., and Havens, I. (1959). Blood transfusions and serum hepatitis. Ann. Surg., 150, 455-468.

-, and Sayman, W. A. (1962). Serum hepatitis from transfusions of blood. Epidemiologic study. J. Amer. med. Ass., 180, 1079. 1085.

Anderson, R. A., Lou, K., and Allen, N. K. (1965). Transaminase levels in a blood donor population. (Proc. 10th Congr. int. Soc. Blood Transf., Stockholm, 1964), Bibl. Haemat., 23, $1062-1065$.

Bang, N. U., Ruegsegger, P., Ley, A. B., and Ladue, J. S. (1959). Detection of hepatitis carriers by serum glutamic oxalacetic transaminase activity. J. Amer. med. Ass., 171, 2303-2306.

Creutzfeldt, W. (1966). Die transfusionshepatitis und ihre Verhütung. Internist (Berl.), 7, 1-8.

Grady, G. F., Chalmers, T. C., and the Boston Inter-Hospital Liver Group (1964). Risk of post-transfusion viral hepatitis. New Engl. J. Med., 271, 337-342.

Hampers, C. L., Prager, D., and Senior, J. R. (1964). Post-transfusion anicteric hepatitis. Ibid., 271, 747-754.

Havens, W. P., Jr. (1961-62). Viral hepatitis. Yale J. Biol. Med., 34, 314-328.

International Union of Biochemistry (1961). Report of the Commission on Enzymes, Pergamon Press, Oxford.

Katz, R., Ducci, H., Bennett, H., and Rodríguez, J. (1957). Incidence of hepatitis following transfusions of whole blood. Amer. J. clin. Path., 27, 406-421.

Lehane, D., Kwantes, C. M. S., Upward, M. G., and Thomson, D. R. (1949). Homologous serum jaundice. Brit. med. J., 2, 572-574.

McCollum, R. W. (1962). Epidemiologic patterns of viral hepatitis. Amer. J. Med., 32, 657-664.

Mirick, G. S., Ward, R., and McCollum, R. W. (1965). Modification of post-transfusion haepatitis by gamma globulin. New Engl. J. Med., 273, 59-65.

Norris, R. F., Potter, H. P., Jr., and Reinhold, J. G. (1963). Present status of hepatic function tests in the detection of carriers of viral hepatitis. Transfusion (Philad.), 3, 202-210.

Reitman, S., and Frankel, S. (1957). A colorimetric method for the determination of serum glutamic oxalacetic and glutamic pyruvic transaminases. Amer. J. clin. Path., 28, 56-63.

Rowland, A. J., Skone, J. F., Wofinden, R. C., and Wood, A. J. (1967). Infectious hepatitis in Bristol, 1960-6. Brit. med. J., 1, 309-310.

Shimada, N., Fukuda, T., Ishii, Y., Sekikawa, D., Ohtsuki, M., Matsuda, H., Kodeki, K., Ohya, G., Nagao, F., Kimura N., Nakano, S., Murakami, S., Miyamoto, S., and Tsuchiya, T. (1965). Serum hepatitis in Japan. (Proc. 10th Congr. int. Soc. Blood Transf., Stockholm, 1964), Bibl. Haemat., 23, 1066-1070.

Shimizu, Y., and Kitamoto, O. (1963). The incidence of viral hepatitis after blood transfusions. Gastroenterology, 44, 740-744.

Torii, A., Nakano, S., and Miyazato, Y. (1965). The use of gammaglobulin in the prevention of serum hepatitis. (Proc. 10th Congr. int. Soc. Blood Transf., Stockholm, 1964), Bibl. Haemat. 23, $1055-1057$. 